\title{
Investigation and Analysis on the Concept and Behavior Characteristics of Eating Game in Mainland China
}

\author{
Linhai Wang ${ }^{1}$, Wenqi Zhang ${ }^{2}$, Yuexi $\mathrm{Du}^{3}$ and Zuogong Wang ${ }^{4,5^{*}}$ \\ ${ }^{1}$ Department of Senior Three, Zhengzhou Foreign Language Middle School, Zhengzhou, Henan, China \\ ${ }^{2}$ Department of economics, Henan University, Kaifeng, Henan, China \\ ${ }^{3}$ Department of language and communication, Beijing Jiaotong University, Beijing, China \\ ${ }^{4}$ Cultural Heritage and Innovation Research Center (Project Code 2020CY017),Henan University,Kaifeng, Henan, China \\ ${ }^{5}$ Digital Inclusive Finance Cooperation Center, Henan University, Kaifeng, Henan, China
}

\begin{abstract}
COVID-19 and SARS are two major infectious diseases that broke out in mainland China in the 21st century. Wild animals are hosts of SARS-CoV-2 and SARS-CoV. But in many areas of mainland China, there are traditional customs of eating game. Through online questionnaire survey, this paper finds that there are still many defects in the cognition, attitude, consumption habits and behaviors of Chinese mainland residents to game. Moreover, there are significant differences in cognition, attitude, consumption habits and behavior characteristics of game among residents of different genders, occupations and income levels in mainland China. It is important to point out that the civil servants and high-income groups of China show more deficiencies in the above aspects. In view of the problems found in the investigation, this paper puts forward relevant suggestions to prevent the risk of infectious diseases caused by eating game in mainland China.
\end{abstract}

\section{Introduction}

In December 2019, COVID-19 first appeared in Wuhan, Hubei Province, China. As of June 4, 2020, 6,416,828 confirmed cases had occurred in 221 countries in the world, including 83,027 in mainland China; 382,867 deaths had occurred in the world, including 4,634 in mainland China . Tedros Adhanom, the director-general of the WHO, announced on February 28, 2020 that the global risk assessment of COVID-19 would be raised from the previous "high" to "very high". Roujian Lu, Xiang Zhao and others (2020) analyzed the genome sequences of 9 Wuhan patients who suffered from COVID-19. They first confirmed that the hosts of SARS-CoV-2 are bats which from Zhoushan, the eastern of China [1]. Zhengli Shi, Wuhan Institute of Virology, Chinese Academy of Sciences (2020), found that SARS$\mathrm{CoV}-2$ is $96 \%$ identical at the whole-genome level to a bat coronavirus [2].On February 29, 2020, National Health Commission of the People's Republic of China released Investigation Report of COVID-19 by China and WHO which pointed out that bats seem to be the hosts of SARS-CoV-2 [3]. About the intermediate host of SARS-CoV-2, there are different voices in academia. Two research teams have claimed that the pangolins (Malayan pangolins) [4] and the turtles (C. picta bellii, C. mydas, and P. sinensis) [5] may act as the potential intermediate hosts transmitting SARS-CoV-2 to human. However, there is no exact conclusion about which kind of wild animal is the intermediate host. Jiatong Zhuo,
Zhigang Zheng and Wenkui Geng analyzed the genome sequences of patients who suffered from SARS and found that the SARS virus in masked palm civet had 99\% homology with SARS-CoV [6].COVID-19 and SARS are two major infectious diseases that broke out in mainland China in the 21st century. The researche above indicate that wild animals are hosts of SARS-CoV-2 and SARS-CoV. In addition, it had been confirmed that the most likely hosts of Ebola virus, which broke out in the tropical rainforests of Africa and Southeast Asia in the 20 th and 21 st century, were also the wild animal fruit bats [7-8]. Just as Juliet Bedford and other epidemiologists said that, the fact that pools of viruses, bacteria and parasites are maintained in wild and domesticated animals makes surveillance of potentially zoonotic diseases an intrinsic part of One Health epidemic planning [9].

On the other hand, the species, quantity and living space of wild animals are also facing challenges. According to the Living Planet Report-2018: Aiming Higher released by WWF, the number of global wildlife had declined by $60 \%$ in the past 40 years due to pollution, deforestation, climate change and human factors [10].

However, It is worrying that there are traditional customs of eating game in many parts of the world. Common game species in North America include bears, bison, antelope, caribou, moose, reindeer, boar, snake, alligator, rabbit, squirrel, beaver and birds (pheasant, grouse, quail, pheasant, wild goose and wild duck). The

\footnotetext{
* Corresponding author:Zuogong Wang 228343533@qq.com
} 
Department for Environment, Food and Rural Affairs (DFRA) estimates that nearly 12000 tons of smuggled bush meat enter the UK every year, while bush meat carries Foot-and-mouth disease virus, Ebola virus, monkey pox, and Rift valley fever virus [11]. Xiduo Guo 's research(2003) showed that in 21 large and mediumsized cities in China, more than $50 \%$ of restaurants handled dishes processed by wild animals, and $46.2 \%$ of urban residents had eaten wild animals [12].According to Qing Yang (2000), 2-30 tons of live wild animals are transported into China every day [13].

In order to analyze the cognition, attitude and behavior characteristics of Chinese residents to game, we held an online questionnaire survey. The paper is based on the survey.

\section{Basic situation}

From 11:23 a.m. on February 23, 2020 to 9:00 a.m. on February 24, 2020, the survey was completed through https://www.wjx.cn/, which is a professional platform in China named "Wenjuanxing" for data collection questionnaire survey. You can see the questionnaire in S1 File. 528 valid responses had been received through this survey. The basic information of the respondents are as follows:

In terms of gender, 210 cases are male, accounting for $39.77 \%$, 318 cases are female, accounting for $60.23 \%$.

In terms of age, there are 8 cases of under- 18 , accounting for $1.52 \%$; 8 cases of over- 60 accounting for $1.52 \% ; 328$ cases of between 19 and 40, accounting for $62.12 \% ; 184$ cases of between 41 and 59 , accounting for $34.85 \%$.

In terms of education background, there are 37 cases of high-school-educated or below, accounting for 7.01\%; 49 cases of Junior college degree, accounting for $9.28 \%$; 314 cases of bachelor degree, accounting for $59.47 \%$; 128 cases of graduate degree, accounting for $24.24 \%$.

In terms of occupation, there are 250 cases of students, accounting for $47.35 \% ; 117$ cases of enterprise employees, accounting for $22.16 \%$; 89 cases of public institutions (social organizations) employees, accounting for $16.86 \%$; 43 cases of freelancers, accounting for $8.14 \% ; 29$ cases of civil servants, accounting for $5.49 \%$. As shown in Fig 1.

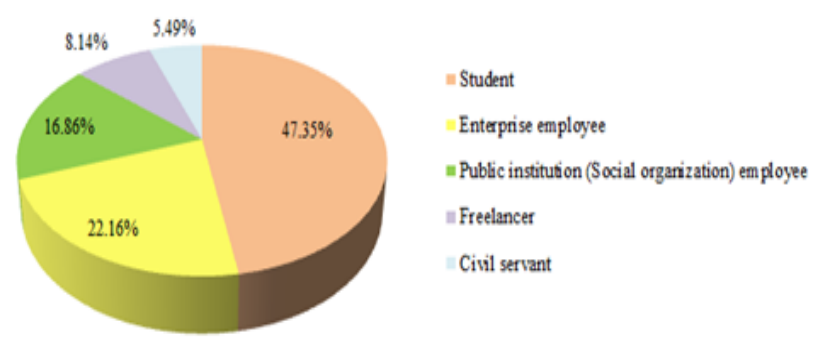

Fig 1. Pie chart of occupations

In terms of annual income, there are 306 cases of under-RMB 60000 , accounting for $57.95 \% ; 143$ cases of RMB 60000-120000, accounting for $27.08 \%$; 60 cases of RMB 120000-300000, accounting for $11.36 \%$; 19 cases of over-RMB 300000, accounting for 3.60\%. As shown in Fig 2.

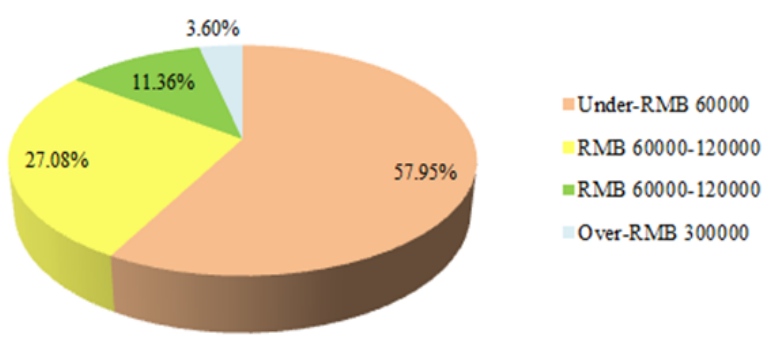

Fig 2. Pie chart of annual income levels

\section{Analysis}

\subsection{Integrated analysis}

On the question of eating game, $19.89 \%$ of the respondents had eaten game; and $80.11 \%$ of the respondents had not eaten game, indicating that only a few of them, nearly one fifth of the respondents had eaten game.

On the question of the safety of eating game, only $1.52 \%$ of the respondents think that it is safe to eat game; $9.28 \%$ of the respondents think that only the game provided by regular shops and restaurants is safe; and the rest $89.2 \%$ of the respondents think that game has security risks.

This result shows that the vast majority of respondents have a correct understanding of the safety of game. But combined with the results of the question of eating game, we can find that there are still some people who hold some lucky psychology to eat game even though they know that game has potential safety hazards.

On the question of the nutrition of game, $83.33 \%$ of the respondents think that there is no difference between game and general food; $8.33 \%$ of the respondents think that game is not as nutritious as general food and $8.33 \%$ of the respondents think that game is more nutritious than general food.

On the question of the taste of game, $44.51 \%$ of the respondents think that the taste of wild game is the same as that of general food, $39.39 \%$ think that the taste of wild game is inferior to that of general food, and only $16.10 \%$ think that the taste of wild game is better than that of general food.

On the question of the reason of eating game, the number of respondents who think that eating game is out of curiosity is the largest, accounting for $62.12 \%$; the proportion of respondents who think that eating game is because of the rich nutrition of game is $13.45 \%$; the proportion of respondents who think that eating game is because of the good taste of game is $8.52 \%$; another $15.91 \%$ of the respondents think that it is other reasons. As shown in Fig 3. 


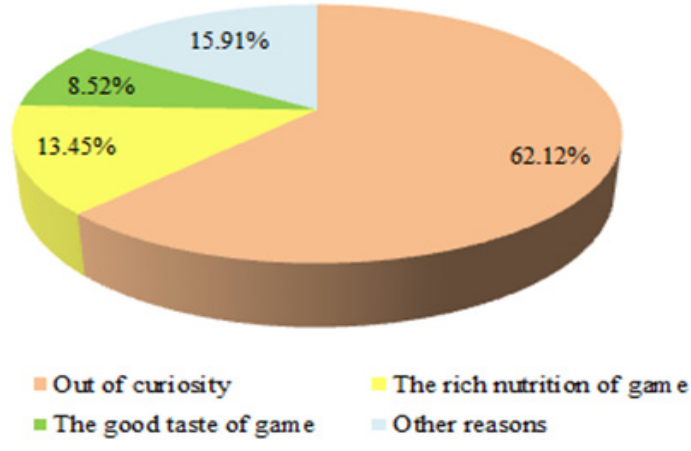

Fig 3. Pie chart of the reason of eating game

On the question of the relationship between eating game and SARS and COVID-19, $75.76 \%$ of the respondents believe that eating game is relevant to SARS and COVID-19; $22.35 \%$ of the respondents think it is uncertain; $1.14 \%$ of the respondents believe that eating game is relevant to SARS, and has no relationship with COVID-19; the remaining $0.76 \%$ think there is no relationship among the three. As shown in Fig 4.

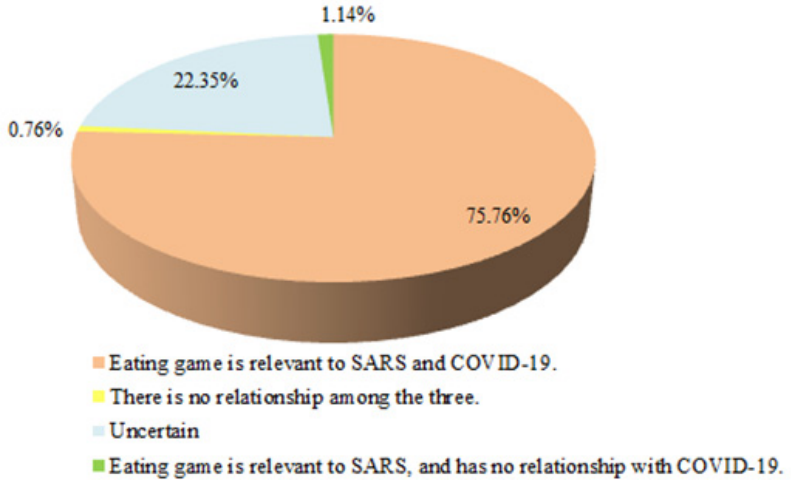

Fig 4. Pie chart of the relationship between eating game and SARS and COVID-19

This shows that most of the respondents have a certain sense of crisis, and they have a certain understanding of the source of infectious diseases and related research progress.

On the question of the legality of eating game which is outside the list of wild animals enacted by governments at all levels and relevant departments, $63.26 \%$ of the respondents think it is illegal, only $11.36 \%$ of the respondents think it is legal, and $25.38 \%$ of the respondents are uncertain. As shown in Fig 6.

On February 24, 2020, the Standing Committee of the National People's Congress passed the decision of the Standing Committee of the National People's Congress on banning the trade of illegal wild animals in an allround way, getting rid of the bad habit of eating wild animals indiscriminately and ensuring the life, health and safety of the people. Before this decision, only wild animals under special state protection and other protected wild animals without legal source and without quarantine qualification were prohibited from eating by law. This shows that most of the respondents are not clear about the provisions of the law on wild animals.

On the question of the safety of eating game which is outside the list of wild animals enacted by governments at all levels and relevant departments, only $2.27 \%$ of the respondents think it is safe, the vast majority of the respondents think it is unsafe, accounting for $76.14 \%$, and the remaining $21.59 \%$ are uncertain.

On the question of the most important measures to be taken to prevent infectious diseases caused by eating wild animals, $36.55 \%$ of the respondents think that people should take the initiative to change their eating culture and habits and consciously not to eat game. The remaining $63.44 \%$ of the respondents wanted to restrict people from eating game by legal means. It can be seen that at present, most of the respondents are relatively exclusive to the behavior of eating game.

\subsection{Difference analysis}

\subsubsection{Difference in gender}

It is found that not only the proportion of women participating in the survey is significantly higher than that of men, but also women's attitude towards game is more rational, and they have different behavior characteristics from men.

On the question of eating game, $12.58 \%$ of the female respondents had eaten game,but $31.43 \%$ of the male respondents had eaten game, the proportion of the male respondents who had eaten game is twice that of the female respondents; $87.74 \%$ of the female respondents had not eaten game, which is also significantly higher than $68.57 \%$ of the male respondents.

On the question of the safety of eating game, $1.26 \%$ of female respondents think it is safe to eat game, which is lower than $1.9 \%$ of males; $7.55 \%$ of female respondents think that the game provided by regular shops and restaurants is safe, which is lower than $11.9 \%$ of males; $91.2 \%$ of female respondents think that game has security risks, which is higher than $86.19 \%$ of males.

On the question of the nutrition of game, $87.11 \%$ of the female respondents think that there is no difference between the nutrition of game and the general food, but only $77.62 \%$ of the males.

On the question of the taste of game, only $11.01 \%$ of female respondents think that the taste of game is better than that of general food, significantly lower than $23.81 \%$ of males; $47.17 \%$ of female respondents think that the taste of game is worse than that of general food, significantly higher than $27.62 \%$ of males.

On the question of the legality of eating game which is outside the list of wild animals enacted by governments at all levels and relevant departments, Fig 5 shows the double layer pie chart of males and females options. 


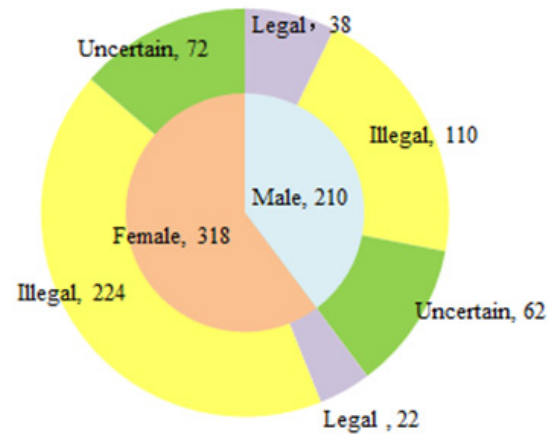

Fig5. Double layer pie chart of males and females options on the question of the legality of eating game which is outside the list of wild animals enacted by governments at all levels and relevant departments.

Among the female respondents, 224 think illegal, accounting for $70.44 \%$, significantly higher than 110 males, accounting for 52.38\%; only 22 female respondents think legal, accounting for $6.92 \%$, significantly lower than 38 male respondents, accounting for $18.1 \%$. This suggests that women have more emotional rejection of eating game, even though it is legal to eat the above-mentioned game in the survey.

On the question of the safety of eating game which is outside the list of wild animals enacted by governments at all levels and relevant departments, Fig 6 shows the double layer pie chart of males and females options.

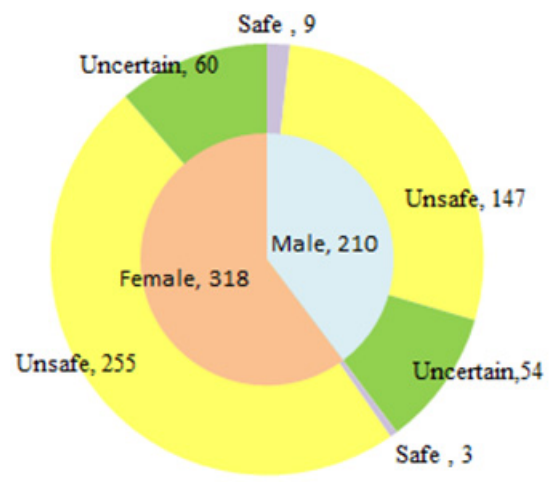

Fig 6. Double layer pie chart of males and females options on the question of the safety of eating game which is outside the list of wild animals enacted by governments at all levels and relevant departments

225 female respondents think it is unsafe, accounting for $80.19 \%$, significantly higher than $147,70.00 \%$ of males, and only $0.94 \%$ of female respondents think it is safe, also significantly lower than $4.29 \%$ of male respondents. This further confirms the female's emotional rejection of eating game.

Joanna Burger (2000) also found gender differences in wildlife consumption. Women were less likely to eat most types of game than were men and consumed significantly fewer meals of game than did men [13]. To a large extent, this is consistent with the conclusion of this paper.

\subsubsection{Difference in occupation}

In this survey, 5 occupations have been set up, including student, freelancer, enterprise employee, public institution (social organization) employee and civil servant.

On the question of eating game, the highest proportion of civil servants who had eaten game is $41.37 \%$, followed by freelancers, accounting for $25.26 \%$. The proportion of enterprise employees, public institutions (social organizations) employees and students who had eaten wild game was $23.93 \%, 20.22 \%$ and $14.4 \%$ respectively.

And on the question of the reason for eating game, the proportion of civil servants who think that eating game is because of the good taste of game is also the highest, accounting for $17.24 \%$, and the proportion of students is the lowest, accounting for $7.6 \%$. The proportion of civil servants who think that eating game is out of curiosity is the lowest, accounting for $44.83 \%$, while the proportion of students is the highest, accounting for $63.20 \%$.

On the question of the nutrition of game, although the vast majority of respondents from all occupations think that there is no difference between the nutrition of game and the general food, the proportion of civil servants who think that game is rich in nutrition is the highest, accounting for $20.69 \%$, the proportion of students is the lowest, accounting for $5.2 \%$.

On the question of the taste of game, the proportion of civil servants who think that the taste of game is better than that of general food is $34.48 \%$, significantly higher than that of other occupations, the proportion of students is the lowest, accounting for $8 \%$.

On the question of the safety of eating game, although the vast majority of respondents in all occupations believe that game has security risks and eating game is unsafe, the proportion is the lowest among the civil servants, accounting for $82.76 \%$.

On the question of the relationship between eating game and SARS and COVID-19, in all occupations, over $65 \%$ of the respondents believe that eating game is related to the two epidemics. Among them, the highest proportion is students, accounting for $80.00 \%$, and the lowest is civil servants, accounting for $68.97 \%$. As shown in Table 1. 
Table 1. The proportion of different occupational groups in the above options.

\begin{tabular}{|c|c|c|c|c|}
\hline & $\begin{array}{c}\text { Game is } \\
\text { rich in } \\
\text { nutrition }\end{array}$ & $\begin{array}{c}\text { Game } \\
\text { tastes } \\
\text { good }\end{array}$ & $\begin{array}{c}\text { Game } \\
\text { is } \\
\text { unsafe }\end{array}$ & $\begin{array}{c}\text { Game is } \\
\text { related to } \\
\text { SARS\&C } \\
\text { OVID-19 }\end{array}$ \\
\hline $\begin{array}{c}\text { Civil } \\
\text { servant }\end{array}$ & $20.69 \%$ & $34.4 \%$ & $82.76 \%$ & $68.97 \%$ \\
\hline $\begin{array}{c}\text { Enterprise } \\
\text { employee }\end{array}$ & $12.82 \%$ & $28.2 \%$ & $91.45 \%$ & $71.79 \%$ \\
\hline Freelancer & $9.30 \%$ & $18.6 \%$ & $90.69 \%$ & $72.09 \%$ \\
\hline $\begin{array}{c}\text { Public } \\
\text { institution } \\
\text { (Social org- } \\
\text { anization) } \\
\text { employee }\end{array}$ & 6.74 & $15.7 \%$ & $89.88 \%$ & $73.03 \%$ \\
\hline Student & $5.20 \%$ & $8.00 \%$ & $88.4 \%$ & $80.0 \%$ \\
\hline
\end{tabular}

Among the respondents who chose the two options of rich nutrition and good taste of game, the proportion of civil servants is significantly higher than that of other professions, while the proportion of students is the lowest. Among the respondents who chose the two options, wild game is unsafe, wild game is related to SARS and COVID-19, the proportion of civil servants is lower than that of other occupations, and the proportion of students is higher. Also, the proportion of the civil servants who had eaten wild game is the highest, and the proportion of the students is the lowest. Combined with the cognition of civil servants and students on the nutrition, taste, and safety of game, we can infer that civil servants are also the most likely to be game eaters in all professions, while students are the least likely to be game eaters.

On the question of the legality of eating game which is outside the list of wild animals enacted by governments at all levels and relevant departments, more than $55 \%$ of respondents in all occupations think illegal. Among them, the proportion of public institutions (social organizations) employees is the lowest, accounting for $55.06 \%$, and the proportion of civil servants is slightly higher, accounting for $58.62 \%$. And less than $20 \%$ of respondents in all occupations think legal. On February 24, 2020, the Standing Committee of the National People's Congress passed the decision of the Standing Committee of the National People's Congress on banning the trade of illegal wild animals in an all-round way, getting rid of the bad habit of eating wild animals indiscriminately and ensuring the life, health, and safety of the people. Before this decision, only wild animals under special state protection and other protected wild animals without legal source and quarantine qualification were prohibited from eating by law. This shows that most of the respondents are not clear about the provisions of the law on wild animals.

On the question of the most important measures to be taken to prevent infectious diseases caused by eating animals, among the five professions, the proportion of civil servants who think that people should take the initiative to change their eating culture and habits and consciously not to eat game is the highest, which is $58.62 \%$, while the proportion of civil servants who think that laws should be made to prohibit eating wild game by compulsory means is $41.38 \%$. This shows that the civil servants who play a leading role in making laws do not want to make laws, but rather prefer to change people's diet culture and habits to prevent the infectious diseases caused by eating game.

The public, humanity and ethics should be the three main meanings of the spirit of civil servants. However, in recent years, some scholars have found that the public, humanistic and ethical spirits of civil servants in China are in varying degrees of lack. In the public aspect, it is mainly reflected in the lack of moral character of civil servants; in the humanistic aspect, it is mainly reflected in the lack of civil servants' humanism to society and people; in the ethical aspect, it is mainly reflected in the lack of civil servants' concept of rule of law and public servants' awareness[15-17].It is found that civil servants have many deficiencies in the behavior of eating game, the cognition of game, and the legal understanding of game. To some extent, these deficiencies confirm the above view.

\subsubsection{Difference in income level}

The respondents of different income levels also have different understanding and behavior of game. In this survey, 4 stages of annual income level have been set up, including under-RMB 60000, RMB 60000-120000, RMB 120000-300000 and over-RMB 300000.

On the question of eating game, the proportion of the respondents whose annual income level is over-RMB 300000, RMB 120000-300000, RMB 60000-120000 and under-RMB 60000 who have eaten game is $52.63 \%$, $30 \%, 19.59 \%$ and $16.01 \%$, respectively. This shows that the higher the income level, the higher the proportion of people eat game.

On the question of the safety of eating game, the proportion of respondents with an annual income of over-RMB 300000 who think that game has security risks is $94.47 \%$.

On the question of the nutrition of game, the proportion of respondents with an annual income of over-RMB 300000 who think there is no difference between game and general food is $94.74 \%$

On the question of the taste of game, the proportion of respondents with an annual income of over-RMB 300000 who think that game tastes as good as general food is $47.37 \%$.

On the question of the reason of eating game, the proportion of respondents with an annual income of over-RMB 300000 who think that eating game is out of curiosity is $73.68 \%$.

On the question of the relationship between eating game and SARS and COVID-19, the proportion of respondents with an annual income of over-RMB 300000 who believe that eating game is relevant to SARS and COVID-19 is $89.47 \%$.

On the question of the legality and safety of eating game which is outside the list of wild animals enacted by governments at all levels and relevant departments, the proportion of respondents with an annual income of 
over-RMB 300000 who think it is illegal and unsafe is $68.42 \%$ and $78.95 \%$ respectively.

Among the above eight questions, the proportion of the respondents with an annual income of over-RMB 300000 who choose the above eight options is the highest among all income groups. This shows that although the respondents with the highest income have a clear and rational understanding of wild game, can realize that eating game is unsafe and is related to infectious diseases, and the taste and nutrition of game are the same as that of general food, but because of curiosity, the proportion of eating game is the highest.

Due to the influence of traditional consumption culture, foreign consumption culture and mainstream culture, the formation of middle classes consumption behavior and consumption ethics in China are characterized by diversification and complexity. The middle classes show individuality and taste through consumption, and pays attention to the "fashion value" and "symbolic value" embodied in commodities in consumption activities [18]. For the middle classes, they are more likely to regard "eating game" as a means of expressing their taste and personality, as a "fashion" and a "trend". They are constantly catching up with the socalled "fashion", expressing their own value through the "symbolic value" transmitted by fashion, in order to obtain a higher social reputation and status. The contradiction between the rational game cognition and the irrational game consumption behavior of the middle classes found in this paper confirms this view to a large extent.

\section{Conclusions}

According to the problems found in the investigation, it is suggested to prevent the risk of infectious diseases caused by eating game in mainland China from the following aspects:

First, we should strengthen the publicity and education on the basic knowledge of game, including the nutrition of game, the relationship between game and infectious diseases, and the laws and regulations of game. Also, government should help people consciously develop a diet culture and habit of not eating game and keeping away from it.

Second, it is necessary to strengthen the education and management of civil servants. It is found that civil servants have many deficiencies in the behavior of eating game, the cognition of game, and the legal understanding of game. More importantly, civil servants play a leading role in China's governance, so we must strengthen the education and management of civil servants.

Third, the society should strengthen the guidance and management of high-income groups. From the investigation, we can see that the higher the income of the respondents, the higher the proportion of eating game. Moreover, the high-income respondents have a more rational understanding of the nutrition, taste, safety of game and the relationship between game and infectious diseases. The contradiction between the rationality of cognition and the irrationality of behavior makes us realize that we should strengthen the guidance and management of high-income groups and form rational and scientific eating habits.

Finally, appropriate laws and regulations should be formulated, and the enforcement of law should be strengthened to ensure that people can have the legal basis that must be followed.

\section{Fund:}

Scientific research projects in 2020 Building a modern governance system based on community theory in the post epidemic era from the perspective of cultural differences (2020CY017) Cultural heritage and innovation research center of Henan University;

Key projects of NSFC Research on national governance capacity and performance measurement index system (19ATJ005) School of economics, Henan University.

Thanks to Bingtao Song, professor of Henan University and Liangbo Zhai, doctor of Zhejiang University for their help and dedication to our manuscript.

\section{References}

1. R.Lu, G.Wu, W.Shi, J. Li, P.Niu,.et.al. Genomic characterization and epidemiology of 2019 novel coronavirus: implications for virus origins and receptor binding Lance 395,565 (2020)

2. P.Zhou, X. Yang, X.Wang, B.Hu, L.Zhang.et.al. A pneumonia outbreak associated with a new coronavirus of probable bat origin Nature 579,270 (2020)

3. Joint investigation group from China and WHO. Investigation Report of COVID-19 by China and WHO. Available at: http://www.nhc.gov.cn/. (2020)

4. K.Xiao, J.Zhai.et al. Isolation and Characterization of 2019-nCoV-like Coronavirus from Malayan Pangolins BioRxiv (2020)

5. Z.Liu, X.Xiao, X.Wei. Composition and divergence of coronavirus spike proteins and host ACE2 receptors predict potential intermediate hosts of SARS-CoV-2 MV (2020)

6. J.Zhuo, Z.Zheng, W.Geng. Progress in the study of SARS pathogen, host and transmission pathway APM 3,187(2008)

7. E.M.Leroy, B.Kumulungui, R.Swanepoel, et al. Fruit bats as reservoirs of Ebola virus Nature 438, 575(2005)

8. R.Biek,P.D.Walsh, E.M.Leroy,A.R.Leslie. Recent common ancestry of Ebola Zaire virus found in a bat reservoir PP 2, e90(2003)

9. Bedford,J.,Farrar,J.,Ihekweazu,C.,Kang,G.,Koopma ns,M.,Nkengasong,J. A new twenty-first century science for effective epidemic response. Nature 575,130-136(2019) 
10. WWF. Living Planet Report-2018: Aiming Higher. Available at:https://www.worldwildlife.org/\#.(2018)

11. G.Ling,C.Yan. Food safety and management problems caused by game in America EH 1,47 (2006)

12. X.Guo.Consumption behavior of game and its harm to human body MR 3, 5 (2003)

13. Q.Yang, J.Chen, Z.Bai, X.Deng, Z.Liu. Trade of wild animals and plants in China-Laos border areas: status and suggestion for effective management. BS 3,284-296 (2000)

14. Joanna Burger. Gender Differences in Meal Patterns: Role of Self-Caught Fish and Wild Game in Meat and Fish Diets. ER 83 2,140-149 (2020)

15. J.Ke. Public, humanity and Ethics: the three essentials of the spirit of civil servants MT 1, 34 (2007)

16. L.Zhu.The lack and reconstruction of civil servants' humanistic spirit EMER 3,24 (2007)

17. X.Guo. The lack of ethical spirit of civil servants in China LS 25, 45 (2016)

18. D.Chen Analysis of the consumption behavior and consumption ethics of the contemporary middle classes. CE 9,141-142 (2012) 